\title{
Development of West African yam Dioscorea spp. core collection
}

\author{
V. Mahalakshmi $\cdot$ N. Ng $\cdot$ J. Obidiegwu \\ D. Ogunsola $\cdot$ M. Lawson $\cdot$ R. Ortiz
}

Published online: 14 April 2007

(C) Springer Science+Business Media B.V. 2007

\section{Erratum to: Genet Resour Crop Evol: DOI 10.1007/s10722-006-9203-4}

The correct names of the authors should have been:
V. Mahalakshmi, N. Ng, J. Obidiegwu, D. Ogunsola, M. Lawson, R. Ortiz Instead of:

V. Mahalakshmi, N. Ng, J. Atalobhor, D. Ogunsola, M. Lawson, R. Ortiz

The online version of the original article can be found at http://dx.doi.org/10.1007/s10722-006-9203-4

V. Mahalakshmi $\cdot$ N. Ng $\cdot$ J. Obidiegwu .

D. Ogunsola $\cdot$ M. Lawson

International Institute of Tropical Agriculture (IITA),

Oyo Road, Ibadan, PMB 5320, Nigeria

Present Address:

N. Ng

Food and Agriculture Organization (FAO) Regional, Office for Asia and Pacific, 39 Phrqa Atit Road,

Bangkok 10200, Thailand

R. Ortiz $(\bowtie)$

Centro Internacional de Mejoramiento de Maíz y Trigo (CIMMYT), Apdo. Postal 6-641, Mexico, DF 06600, Mexico

e-mail: r.ortiz@cgiar.org 